\title{
Measures stated by parents and caregivers of infants, toddlers, and preschoolers to prevent environmental tobacco smoke exposure
}

\author{
Sandra Ríos, B.S. ${ }^{a}$, Joselyn Concha, B.S. ${ }^{a}$ and R. Mauricio Barría, Dr PH ${ }^{b}$
}

\begin{abstract}
Introduction. The exposure to environmental tobacco smoke is a publichealth problem because of its potential risks for children.

Objective. To determine the preventive actions taken by parents and/or caregivers of infants, toddlers, and preschoolers regarding environmental tobacco smoke exposure.

Methods. Cross-sectional, analytical study in parents and caregivers of infants, toddlers, and preschoolers from Valdivia, Chile. A questionnaire on preventive measures regarding environmental tobacco smoke was administered. The questionnaire was analyzed with descriptive and association statistics using Fisher's exact test and logistic regression to calculate the odds ratios (ORs) and their corresponding 95\% confidence intervals (95\% CIs) as an estimation of the risk for not taking preventive measures at home.

Results. A total of 469 parents and caregivers participated. The prevalence of households with one member who smoked was $51.8 \%$. Most of them smoked outside the house $(92.2 \%)$. The most common measure taken outside the household was to avoid places where people smoked. In this setting, a significant difference was observed between men and women in relation to avoiding exposure $(7.6 \%$ versus $2.2 \%$; $\mathrm{p}=0.040)$. A higher risk for not avoiding tobacco use inside or outside the housewas confirmed when a household member smoked (OR: 3.55; 95\% CI: 2.05-6.14). Also, a lower risk was observed when there were two or more children in the household (OR: 0.46; 95\% CI: 0.26-0.83).

Conclusions. Most parents and caregivers ask others to smoke outside and avoid places where people smoke; however, the level of prevention is lower among households with smokers.

Key words: preschooler, smoking, tobacco smoke pollution.
\end{abstract}

http: / / dx.doi.org/10.5546/ aap.2018.eng.262

To cite: Ríos S, Concha J, Barría RM. Measures stated by parents and caregivers of infants, toddlers, and preschoolers to prevent environmental tobacco smoke exposure. Arch Argent Pediatr 2018;116(4):262-268.

\section{INTRODUCTION}

Tobacco use is an important public health problem associated with more than seven million deaths every year; six million people are direct users and almost nine hundred thousand are non-smokers exposed to secondhand smoke. ${ }^{1}$ Worldwide, $40 \%, 35 \%$, and $33 \%$ of children, women, and men who do not smoke, respectively, have been exposed to secondhand smoke; the burden of disease has shown to be unequal: children are the most affected ones in terms of disabilityadjusted life years. ${ }^{2}$

The exposure of children to environmental tobacco smoke (ETS) leads mainly to adults who smoke in places where children live and play, which includes exposure to second- and thirdhand smoke. ${ }^{3-6}$ The consequences are given by the susceptibility of children to smoke toxicity and include a higher risk for sudden infant death, middle ear pathology, severe asthma, acute respiratory infection, pneumonia, and impaired lung function, as well as school absenteeism and restricted activities. $^{7,8}$

Therefore, the different governments have implemented policies and interventions aimed at reducing home exposure through education campaigns for parents and at avoiding the exposure of children in public places. ${ }^{9}$ This was evidenced in Chile by the implementation of the anti-smoking law (19419 and 20660). ${ }^{10,11}$

However, in spite of these initiatives, ETS exposure still occurs in outdoor public places and it has not been possible to protect children at the place where they are most vulnerable: their home. ${ }^{12,13}$ 
At a local level, data are available on the prevalence of indoor tobacco use, ${ }^{14-16}$ but there is no information regarding the measures taken to prevent ETS exposure.

The objective was to determine preventive actions taken by parents and caregivers of infants, toddlers, and preschoolers from the city of Valdivia, Chile, to reduce the exposure of children to ETS.

\section{POPULATION AND METHODS}

This study was based on and broadened the findings of the dissertations by researchers SR and JC as a requirement to qualify for their Bachelor of Science in Nursing of Universidad Austral de Chile. An observational, cross sectional design was selected for the study in a sample representative of the city of Valdivia, Chile, to meet the proposed objective in a timely manner. The target population was made up of parents and caregivers of infants, toddlers or preschoolers attending educational facilities in the city of Valdivia. The eligibility criteria were being older than 18 years (based on their discernment and legal competence), living in the city of Valdivia (to facilitate contact and data collection), and being the legal guardian of a child younger than 7 years enrolled in a nursery school or a day-care center that was part of the National Board of Nursery Schools (Junta Nacional de Jardines Infantiles, JUNJI) or Fundación Integra or a registered private facility, besides public schools, publiclysubsidized private schools, and private schools corresponding to the Ministry of Education that offered preschool education (pre-kindergarten and kindergarten).

A probability sample of 469 subjects based on a population of 6624 subjects enrolled in 2013 (report by Fundación Integra, the JUNJI, and the Provincial Department of Education), a prevalence of indoor cigarette smoking of $12.1 \%, 17$ a $95 \%$ confidence level, and a $3 \%$ estimation error were estimated. The sampling was done using a random and stratified technique, proportional by facility and level. This means that out of the randomly selected 21 facilities for infants and 15 facilities for preschoolers, a proportional weighted sample was obtained based on the population of these facilities. The same process was performed within each facility for every level. Potential participants were contacted during facility meetings; then, once the informed consent process was developed, the total number of participants defined by level was randomly selected. To complete the 469 subjects required, 474 individuals were invited because five refused to participate; with this, participation reached $98.9 \%$. No differences were observed in the characteristics of those who were not included in the study and those who were.

Data were collected between April and December 2014 using a self-administered, anonymous questionnaire based on close-ended questions, which was developed based on expert opinion and pilot-tested in a sample similar to that of the study. The pilot test included 31 subjects from a facility that was not selected for participation and that shared similar characteristics with the ones included in the study. As a result, questions were restructured from open to close-ended, and answer options were included. On the basis of this, appearance and content were validated.

The following outcome measures were considered: sociodemographic aspects (age, sex, marital status, level of education, etc. of the father, mother or caregiver), smoking habit (active smoker: yes/no), smoking intensity (cigarettes/day), indoor smoking (yes/no), usual place for smoking, and actions taken to prevent ETS exposure at home. For this outcome measure, only household members who were active smokers were taken into consideration; it included the following: I) smoking outside the house; II) smoking indoors and airing the room; III) smoking in a different room, and IV) not taking any preventive measure. Measures regarding people who smoked but were not part of the household (actions taken at home in the presence of a third-party who smoked) were also assessed, including the following: I) asking them not to smoke; II) asking them to smoke outside the house, and III) allowing them to smoke sometimes. Lastly, actions or measures taken to prevent ETS exposure outside the household were assessed, including the following: I) no prevention; II) avoiding prolonged exposure (i.e., passing by a place where someone was smoking but not staying there); III) avoiding places where people smoked; IV) other.

\section{Statistical analysis}

Collected data were coded and included in data collection sheets in duplicate by two of the researchers for subsequent consistency assessment. The exploratory analysis included detecting missing or inconsistent data and the distribution characteristics of outcome 
measures. Data were analyzed using descriptive statistics with frequency distribution, measures of tendency and dispersion. Categorical and nominal outcome measures, such as sex, marital status, etc., were described as proportions. For quantitative outcome measures (e.g., age, intensity of cigarette smoking, etc.), mean and standard deviation (SD) or median and range were determined, based on the adjustment to normality as assessed by graphic representation (histogram) and the Kolmogorov-Smirnov test. Once the smoking habit status was established, the actions to prevent ETS were described by category (yes/no) and sociodemographic factors. Since the household was the main place of exposure, a multivariate model was developed using logistic regression to assess the effect of different outcome measures on "preventive measures taken at home regarding a thirdparty who smoked." To this end, this outcome measure was dichotomized into: I) did not allow smoking and II) allowed smoking (inside or outside the house). Outcome measures that showed a univariate association with the result and based on the theoretical plausibility criterion were included in the model. Crude and adjusted odds ratios (ORs), and their corresponding 95\% confidence intervals (95\% CIs), were estimated; a $\mathrm{p}$ value $<0.05$ was considered statistically significant. The Stata software, v.11.1 (Stata-Corp, College Station, TX, 2009) was used for analysis.

\section{Ethical aspects}

The study was approved by the Ethics Committee of the Department of Health of Valdivia (Resolution 064, dated March 10 $0^{\text {th }}, 2014$ ) and authorized by the Regional Division of Fundación Integra, the Regional Division of the JUNJI, the Department of Municipal Education Management, and the Provincial Department of Education of Valdivia.

\section{RESULTS}

\section{General characteristics}

Regarding the relationship with the child, it was observed that most participants were the mothers $(72.5 \%)$; the participants' mean age $( \pm \mathrm{SD})$ was 32.9 years \pm 9.2 , their mean level of education corresponded to 13.6 years \pm 4.1 ; most had completed secondary education $(50.8 \%)$ and were married $(38 \%)$ (Table 1). The median number of children in the care of a parent or caregiver was 4; the mean age of children was $4.0 \pm 1.5$ years, ranging between 0.2 and 6 years.

\section{Exposure to environmental tobacco smoke}

It was observed that $51.8 \%$ of households $(n=243)$ included at least one member who smoked. In $140(57.6 \%)$ of these, only one member smoked. Eleven point nine percent of participants stated that they smoked in the presence of children. Among the households of smokers, $56 \%$ of fathers were tobacco users $(n=136)$. They smoked a mean number of $5.1 \pm 4$ cigarettes per day. Of these, 5.9\% smoked 1-4 cigarettes inside the house on a daily basis. The mothers of 130 households $(53.5 \%)$ were tobacco users. They smoked a mean number of $2.8 \pm 2.6$ cigarettes per day. Of these, 9.2\% smoked 1-6 cigarettes inside the house on a daily basis (Table 2). Out of all smokers, $32.5 \%$ stated that they smoked at work; $5.8 \%$, at home; $31.3 \%$, in the street; $67.1 \%$, in the backyard; and $0.8 \%$, in other places.

\section{General preventive measures}

Among the households with smokers $(\mathrm{n}=243)$, 92.2\% smoked outside the house and 3.3\% did not avoid ETS exposure indoors. Three participants (1.2\%) smoked indoors and aired the room, and $3.3 \%$ smoked in a different room. Among

TABLE 1. Sociodemographic characteristics of parents or caregivers $(n=469)$

\begin{tabular}{|c|c|}
\hline \multicolumn{2}{|l|}{ Outcome measure } \\
\hline \multicolumn{2}{|l|}{ Type of caregiver, n (\%) } \\
\hline Father & $97(20.7)$ \\
\hline Mother & $340(72.5)$ \\
\hline Caregiver & $32(6.8)$ \\
\hline Age (years), mean \pm SD (min.-max.) & $32.9 \pm 9.2(18-70)$ \\
\hline Father & $35.5 \pm 8.4(18-55)$ \\
\hline Mother & $30.8 \pm 7.2(18-51)$ \\
\hline Caregiver & $47.0 \pm 14.1(18-70)$ \\
\hline Education (years), mean \pm SD (min.-max.) & $13.6 \pm 4.1(3-24)$ \\
\hline Father & $14.9 \pm 4.3(5-24)$ \\
\hline Mother & $13.5 \pm 3.9(4-24)$ \\
\hline Caregiver & $11.4 \pm 3.8(3-18)$ \\
\hline \multicolumn{2}{|l|}{ Education (type), n (\%) } \\
\hline Primary & $44(9.4)$ \\
\hline Secondary & $238(50.8)$ \\
\hline Higher technical, professional & $187(39.9)$ \\
\hline \multicolumn{2}{|l|}{ Marital status, n (\%) } \\
\hline Single & $156(33.3)$ \\
\hline Separated & $19(4.0)$ \\
\hline Living with a couple & $102(21.8)$ \\
\hline Married & $178(38.0)$ \\
\hline Widow / widower & $2(0.4)$ \\
\hline Divorced & $12(2.6)$ \\
\hline
\end{tabular}

SD: standard deviation; min.: minimum value; max.: maximum value. 
smokers, $34.2 \%$ stated that they had never attempted quitting; $50.6 \%$, had attempted once; and $15.2 \%$, multiple times.

Among all respondents, most $(82.7 \%)$ asked others to smoke outside, and only $3(0.6 \%)$ allowed smoking inside the house. The analysis of sociodemographic outcome measures (Table 3) underscored that the proportion of parents and caregivers who asked others not to smoke was significantly higher in the households with two or more children than in those where there was only one child $(20.6 \%$ versus $10.7 \%$; $\mathrm{p}=0.009)$. A statistically significant difference $(\mathrm{p}<0.001)$ was also observed between households with and without smokers: smoking was prohibited in $25.2 \%$ of households of non-smokers but only in $8.6 \%$ of households with smokers, and even smoking indoors was allowed in $3(1.2 \%)$ of these.

In relation to the measures taken outside the household (Table 4), the most common one was avoiding places where people smoked; a significant difference was observed between men and women in terms of avoiding exposure $(7.6 \%$ versus $2.2 \% ; \mathrm{p}=0.040)$. No significant differences $(p=0.502)$ were observed between the households of smokers and non-smokers in this regard.

TABLE 2. Characteristics of the smoking habit in households with smokers $(n=243)$

\begin{tabular}{lcccccc}
\hline Relationship with the child & $\mathbf{n}$ & \multicolumn{2}{c}{$\begin{array}{c}\text { Smoking on a daily basis } \\
\text { (min.-max.) }\end{array}$} & $\begin{array}{c}\text { Indoor smoker } \\
\mathbf{n}\end{array}$ & $\begin{array}{c}\text { Indoor smoking } \\
\text { (min.-max.) }\end{array}$ \\
\hline Father & 136 & $5.1 \pm 4.0$ & $0.5-20$ & 8 & 5.9 & $1-4$ \\
Mother & 130 & $2.8 \pm 2.6$ & $0.5-17$ & 12 & 9.2 & $1-6$ \\
Siblings & 12 & $6.3 \pm 6.7$ & $1-25$ & 1 & 8.3 & 15 \\
Grandparents & 68 & $6.3 \pm 5.6$ & $0.5-20$ & 5 & 7.4 & $0-10$ \\
Other & 24 & $5.0 \pm 3.4$ & $1-15$ & 1 & 4.17 & 3 \\
Number of smokers & & & & & & \\
Only one & 140 & $4.7 \pm 4.3$ & $0.5-20$ & 8 & 5.7 & $0-6$ \\
Two or more & 103 & $10.0 \pm 8.4$ & $1-60$ & 18 & 17.5 & $0-27$ \\
\hline
\end{tabular}

SD: standard deviation; min.: minimum value; max.: maximum value.

TABLE 3. Preventive measures taken at home regarding third-parties $(n=469)$

\begin{tabular}{|c|c|c|c|c|}
\hline Outcome measure & $\begin{array}{c}\text { Asking others } \\
\text { not to smoke } \\
\text { n } \%\end{array}$ & $\begin{array}{c}\text { Asking others } \\
\text { to smoke outside the house } \\
\text { n } \%\end{array}$ & $\begin{array}{c}\text { Allowing others } \\
\text { to smoke sometimes } \\
\text { n } \%\end{array}$ & $p$ \\
\hline \multicolumn{5}{|l|}{ Caregiver's sex } \\
\hline Male & $21(19.8)$ & $85(80.2)$ & $0(0)$ & \multirow[t]{2}{*}{0.455} \\
\hline Female & $57(15.7)$ & $303(83.5)$ & $3(0.8)$ & \\
\hline \multicolumn{5}{|l|}{ Caregiver's age } \\
\hline$<33$ years old & $36(14.3)$ & $214(84.9)$ & $2(0.8)$ & \multirow[t]{2}{*}{0.322} \\
\hline$\geq 33$ years old & $42(19.3)$ & $174(80.2)$ & $1(0.5)$ & \\
\hline \multicolumn{5}{|l|}{ Child's age } \\
\hline$<2$ years old & $8(16.0)$ & $41(82.0)$ & $1(2.0)$ & \multirow{3}{*}{0.430} \\
\hline Between 2 and 4 years old & $17(14.1)$ & $103(85.1)$ & $1(0.8)$ & \\
\hline$>4$ years old & $53(17.8)$ & $244(81.9)$ & $1(0.3)$ & \\
\hline \multicolumn{5}{|l|}{ Number of children } \\
\hline One & $20(10.7)$ & $166(88.8)$ & $1(0.5)$ & \multirow[t]{2}{*}{0.009} \\
\hline Two or more & $58(20.6)$ & $222(78.7)$ & $2(0.7)$ & \\
\hline \multicolumn{5}{|l|}{ Couple status } \\
\hline Single & $28(14.8)$ & $160(84.7)$ & $1(0.5)$ & \multirow[t]{2}{*}{0.762} \\
\hline In a couple & $50(17.9)$ & $228(81.4)$ & $2(0.7)$ & \\
\hline \multicolumn{5}{|l|}{ Caregiver's level of education } \\
\hline Primary & $10(22.7)$ & $34(77.3)$ & $0(0)$ & \multirow{3}{*}{0.747} \\
\hline Secondary & $37(15.6)$ & $199(83.6)$ & $2(0.8)$ & \\
\hline Technical/professional & $31(16.6)$ & $155(82.9)$ & $1(0.5)$ & \\
\hline \multicolumn{5}{|l|}{ Smokers at home } \\
\hline No & $57(25.2)$ & $169(74.8)$ & $0(0)$ & \multirow[t]{2}{*}{$<0.001$} \\
\hline Yes & $21(8.6)$ & $219(90.1)$ & $3(1.2)$ & \\
\hline
\end{tabular}




\section{Risk for not taking preventive measures at} home

The multivariate model (Table 5) to establish the factors associated with allowing smoking (inside or outside the house) showed that the main risk was the presence of a smoker in the household (adjusted OR: 3.55; 95\% CI: 2.05-6.14).
On the contrary, the presence of more than one child in the household was a protective factor (adjusted OR: 0.46; 95\% CI: 0.26-0.83).

\section{DISCUSSION}

We approached ETS exposure and the preventive measures taken by the caregivers of

TABLE 4. Preventive measures taken outside the household $(n=469)$

\begin{tabular}{|c|c|c|c|c|c|}
\hline $\begin{array}{l}\text { Outcome } \\
\text { measure }\end{array}$ & $\begin{array}{c}\text { No prevention } \\
\text { n } \%\end{array}$ & $\begin{array}{c}\text { Avoiding } \\
\text { prolonged exposure } \\
\mathrm{n} \%\end{array}$ & $\begin{array}{c}\text { Avoiding places } \\
\text { where people smoke } \\
\text { n } \%\end{array}$ & $\begin{array}{l}\text { Other } \\
\text { n \% }\end{array}$ & $p$ \\
\hline \multicolumn{6}{|l|}{ Caregiver's sex } \\
\hline Male & $8(7.6)$ & $7(6.6)$ & $91(85.9)$ & $0(0)$ & \multirow[t]{2}{*}{0.040} \\
\hline Female & $8(2.2)$ & $33(9.1)$ & $316(87.1)$ & $6(1.7)$ & \\
\hline \multicolumn{6}{|l|}{ Caregiver's age } \\
\hline$<33$ years old & $9(3.6)$ & $15(5.9)$ & $224(88.9)$ & $4(1.6)$ & \multirow[t]{2}{*}{0.172} \\
\hline$\geq 33$ years old & $7(3.2)$ & $25(11.5)$ & $183(84.3)$ & $2(0.9)$ & \\
\hline \multicolumn{6}{|l|}{ Child's age } \\
\hline$<2$ years old & $3(6.0)$ & $3(6.0)$ & $44(88.0)$ & $0(0)$ & \multirow{3}{*}{0.865} \\
\hline Between 2 and 4 years old & $4(3.3)$ & $9(7.4)$ & $107(88.4)$ & $1(0.8)$ & \\
\hline$>4$ years old & $9(3.0)$ & $28(9.4)$ & $256(85.9)$ & $5(1.7)$ & \\
\hline \multicolumn{6}{|l|}{ Number of children } \\
\hline One & $6(3.2)$ & $13(7.0)$ & $164(87.7)$ & $4(2.1)$ & \multirow[t]{2}{*}{0.433} \\
\hline Two or more & $10(3.6)$ & $27(9.6)$ & $243(86.1)$ & $2(0.7)$ & \\
\hline \multicolumn{6}{|l|}{ Couple status } \\
\hline Single & $5(2.6)$ & $15(7.9)$ & $167(88.4)$ & $2(1.1)$ & \\
\hline In a couple & $11(3.9)$ & $25(8.9)$ & $240(85.7)$ & $4(1.4)$ & \\
\hline \multicolumn{6}{|c|}{ Caregiver's level of education } \\
\hline Primary & $4(9.1)$ & $2(4.6)$ & $37(84.1)$ & $1(2.3)$ & \multirow{3}{*}{0.309} \\
\hline Secondary & $6(2.5)$ & $24(10.1)$ & $205(86.1)$ & $3(1.3)$ & \\
\hline Technical/professional & $6(3.2)$ & $14(7.5)$ & $165(88.2)$ & $2(1.1)$ & \\
\hline \multicolumn{6}{|l|}{ Smokers at home } \\
\hline No & $7(3.1)$ & $19(8.4)$ & $199(88.1)$ & $1(0.4)$ & \multirow[t]{2}{*}{0.502} \\
\hline Yes & $9(3.7)$ & $21(8.6)$ & $208(85.6)$ & $5(2.1)$ & \\
\hline
\end{tabular}

Table 5. Estimation of the risk for not taking preventive measures at home*

\begin{tabular}{|c|c|c|c|c|c|c|}
\hline Outcome measure & OR (crude) & $95 \% \mathrm{CI}$ & $\mathbf{p}$ & OR (adjusted) & $95 \% \mathrm{CI}$ & p \\
\hline \multicolumn{7}{|l|}{ Caregiver's sex } \\
\hline Male & $* *$ & & & $* *$ & & \\
\hline Female & 1.33 & $0.76-2.31$ & 0.319 & 1.34 & $0.75-2.42$ & 0.315 \\
\hline \multicolumn{7}{|l|}{ Number of children } \\
\hline One & $* *$ & & & $* *$ & & \\
\hline Two or more & 0.46 & $0.27-0.80$ & $0.006+$ & 0.46 & $0.26-0.83$ & $0.010+$ \\
\hline \multicolumn{7}{|l|}{ Couple status } \\
\hline Single & $* *$ & & & $* *$ & & \\
\hline In a couple & 0.80 & $0.48-1.32$ & 0.386 & 1.07 & $0.62-1.87$ & 0.795 \\
\hline \multicolumn{7}{|c|}{ Caregiver's level of education } \\
\hline Primary & $* *$ & & & $* *$ & & \\
\hline Secondary & 1.60 & $0.73-3.51$ & 0.243 & 1.26 & $0.55-2.88$ & 0.584 \\
\hline Technical/professional & 1.48 & $0.66-3.30$ & 0.339 & 1.33 & $0.60-3.09$ & 0.511 \\
\hline \multicolumn{7}{|l|}{ Smokers at home } \\
\hline No & $* *$ & & & $* *$ & & \\
\hline Yes & 3.56 & $2.08-6.11$ & $<0.001 \dagger$ & 3.55 & 2.05-6.14 & $<0.001+$ \\
\hline
\end{tabular}

* Comparison: forbidding smoking versus allowing smoking inside or outside the house; OR: odds ratio; CI: confidence interval;

${ }^{* *}$ : reference category; $t$ : statistically significant association $(p<0.05)$. 
infants, toddlers, and preschoolers of a city in the south of Chile, a scenario that had not been assessed before. Significant differences were observed in the preventive measures taken at home depending on the presence of smokers in the household. Outside the house, although measures were taken to avoid ETS exposure, some parents and caregivers did not prevent exposure, especially men.

A high prevalence of the smoking habit was observed $(51.8 \%)$, but a small percentage $(<10 \%)$ of participants smoked indoors, similar to the $8.7 \%$ observed previously in the households of newborn infants in Valdivia. ${ }^{15}$ Also, in Temuco, $46.3 \%$ of mothers and female caregivers of infants, toddlers, and preschoolers smoked, and $36.8 \%$ of them did it indoors. ${ }^{14}$

At an international level, in Sweden the prevalence of smoking was $7 \%$ in households with infants; ${ }^{18}$ in Canada, it was $22 \%$ in households with children, ${ }^{19}$ and in Portugal, it was $36.7 \%$ in households with children and adolescents younger than 18 years. ${ }^{20}$ In Argentina, on their part, the prevalence of ETS exposure at home was $27.6 \%$ in the general population. ${ }^{21}$

It was established that almost all parents smoked outside the house, which is noteworthy because there was evidence that this reduced exposure to ETS resulting from indoor smoking. ${ }^{22,23}$ Regarding the measures taken towards third-parties who smoked, the most common action was asking them to smoke outside the house, as reported in Sweden, where $56 \%$ described the same action: results were positive but on a smaller scale than those found in this study. ${ }^{18}$ By contrast, in England, data reported that, in $42 \%$ of households, people smoked in the presence of children, which is much higher than the $11.9 \%$ observed in this investigation. ${ }^{24}$

This study also found a significant association between the preventive measures taken regarding ETS at home and the number of children present in the household. This was consistent with the data that demonstrated that households with children were $17 \%$ less likely to experience ETS exposure at home than those without children (OR: 0.83; 95\% CI: 0.80-0.87). ${ }^{19}$

Regarding the preventive measures taken outside the household, most avoided public places where people smoked. This was consistent with a previous study conducted in Santiago, where $83.5 \%$ of participants indicated that it was pleasant to be in smoke-free places. Actually, $25.4 \%$ of smokers stated that they smoked less since the anti-tobacco law was passed. ${ }^{25}$ Consistent with this, it has been proposed that smoke-free public places appear to stimulate the adoption of smoke-free households, a strategy that has been associated with both a higher frequency of quitting attempts and their success. ${ }^{26}$ In Argentina, the regulation of advertising, promotion, and use of tobacco and the prohibition of smoking in closed public areas also led to a reduced exposure to ETS at home. ${ }^{21}$

However, some reports do not show a reduction in parental tobacco use following the implementation of regulations and restrictions. In addition, as parents do not quit smoking, their house remains the main place for smoking when smoking is restricted in public areas. ${ }^{27}$

In relation to specific interventions, some studies have reported changes in the level of particulate matter or nicotine, thus suggesting effective programs to reduce ETS at home. However, pollution persists and requires other strategies to fully protect children. ${ }^{28}$ Thus, it is necessary to combine effective actions to protect children at home, such as the following: I) encouraging parents to quit smoking; II) making interventions aimed at promoting smokefree households; III) implementing regulatory approaches, such as smoke-free households; IV) running public health education campaigns to encourage smoke-free households beyond the extent of regulatory approaches..$^{28}$ That said, there is not sufficient data to recommend one strategy over another to reduce ETS exposure in children or evidence of success in different contexts (healthy children, sick children, the community). ${ }^{29}$ Impact assessments are required accordingly for each context and region so as to establish which interventions are most costeffective.

Finally, considering the outcome measures that were not assessed and that may interact in the relationship between exposure and preventive measures, this study did not analyze the individual characteristics of tobacco use because it centered on family use; children were younger than 7 years, which did not allow us to establish preventive measures regarding older children; lastly, some numbers may have been underestimated due to the pressure of giving a response that was socially acceptable. Such limitation should also be considered in the context of a self-reported measurement that was not biochemically validated, for example, by measuring urine cotinine levels. 
In relation to the measures taken to prevent ETS exposure, this was a ground-breaking study that analyzed the actions taken by parents and caregivers in Chile, so comparisons with the findings of other studies may be different based on the sociocultural contexts where they were developed.

\section{CONCLUSION}

Most parents and caregivers ask others to smoke outside and avoid places where people smoke; however, the level of prevention is lower among households with smokers.

\section{REFERENCES}

1. Organización Mundial delaSalud. Tabaco. Nota descriptiva n. ${ }^{\circ} 339$. OMS 2017. [Accessed on: September 15th, 2017]. Available at: http://www.who.int/mediacentre/ factsheets/fs339/es/.

2. Oberg M, Jaakkola MS, Woodward A, et al. Worldwide burden of disease from exposure to second-hand smoke: a retrospective analysis of data from 192 countries. Lancet 2011;377(9760):139-46.

3. Roberts C, Wagler G, Carr MM. Environmental Tobacco Smoke: Public Perception of Risks of Exposing Children to Second- and Third-Hand Tobacco Smoke. J Pediatr Health Care 2017;31(1):e7-13.

4. Jacob P 3rd, Benowitz NL, Destaillats H, et al. Thirdhand Smoke: New Evidence, Challenges, and Future Directions. Chem Res Toxicol 2017; 30(1):270-94.

5. Figueiro LR, Ziulkoski AL, Dantas DC. Thirdhand smoke: when the danger is more than you can see or smell. Cad Saude Publica 2016; 32(11):e00032216.

6. Acuff L, Fristoe K, Hamblen J, et al. Third-Hand Smoke: Old Smoke, New Concerns. J Community Health 2016; 41(3):680-7.

7. Office on Smoking and Health. The Health Consequences of Involuntary Exposure to Tobacco Smoke: A Report of the Surgeon General. Atlanta, GA: Centers for Disease Control and Prevention; 2006.

8. Rosen LJ, Myers V, Hovell M, et al. Meta-analysis of parental protection of children from tobacco smoke exposure. Pediatrics 2014; 133(4):698-714.

9. Organización Panamericana de la Salud. Exposición al humo de Tabaco Ajeno en las Américas: Una perspectiva de derechos humanos. Washington: OPS; 2006.

10. Ministerio de Salud. Ley n. ${ }^{\circ} 19419$. Regula actividades que indica relacionadas con el tabaco. Santiago, Chile, 22 de septiembre de 1995.

11. Ministerio de Salud, Secretaría de Salud Pública. Ley n. ${ }^{\circ}$ 20660 , modifica ley $n^{\circ} 19419$, en materia de ambientes libres de humo de tabaco. Santiago, Chile, 31 de enero de 2013.

12. Flores A, Iglesias V, Oyarzún M. Exposición a humo de tabaco ambiental: efectos sobre la salud respiratoria infantil. Neumolpediátr 2011; 6:16-21.

13. Bertrand P. Efectos clínicos de la exposición directa e indirecta a tabaco en los niños. Neumolpediátr 2011; 6:8-11.
14. Rivas RE, Barrios CS, Dorner PA, et al. Fuentes de contaminación intradomiciliaria y enfermedad respiratoria en jardines infantiles y salas cuna de Temuco y Padre Las Casas, Chile. Rev Med Chil 2008; 136(6):767-74.

15. BarríaRM,CalvoM,PinoP.Contaminaciónintradomiciliaria por material particulado fino (MP2,5) en hogares de recién nacidos. Rev Chil Pediatr 2016; 87(5):343-50.

16. Barría RM, Calvo M. Factores asociados a infecciones respiratorias dentro de los tres primeros meses de vida. Rev Chil Pediatr 2008; 79(3):281-9.

17. Barría RM. Contaminación aérea intradomiciliaria por material particulado fino (MP2,5) e incidencia de Infección Respiratoria Aguda en los primeros seis meses de vida. [Dissertation]. Santiago: Universidad de Chile; 2012.

18. Johansson A, Halling A, Hermansson G. Indoor and outdoor smoking: impact on children's health. Eur J Public Health 2003; 13(1):61-6.

19. Slogrove AL, Bettinger JA. Home environmental tobacco smoke exposure in Canadian children. Int J Tuberc Lung Dis 2014; 18(4):499-504.

20. Pereira AM, Morais-Almeida M, Sa e Sousa A, et al. Environmental tobacco smoke exposure at home and smoking prevalence in the general Portuguese population-the INAsma study. Rev Port Pneumol 2013; 19(3):114-24.

21. Galante M, Konfino J, Ondarsuhu D, et al. Principales resultados de la 3a Encuesta Nacional de Factores de Riesgo de enfermedades no transmisibles en Argentina. Rev Argent Salud Pública 2015; 6(24):22-9.

22. Matt GE, Quintana PJ, Hovell MF, et al. Households contaminated by environmental tobacco smoke: sources of infant exposures. Tob Control 2004; 13(1):29-37.

23. Johansson A, Hermansson G, Ludvigsson J. How should parents protect their children from environmental tobaccosmoke exposure in the home? Pediatrics 2004;113(4):e291-5.

24. Alwan N, Siddiqi K, Thomson H, et al. Children's exposure to second-hand smoke in the home: a household survey in the North of England. Health Soc Care Community 2010; 18(3):257-63.

25. Amarales L. Estudio de Opinión Pública sobre nueva Ley de Tabaco Demoscópica. 2013. [Accessed on: May 20th, 2016]. Available at: http://www.chilelibredetabaco.cl/ wp-content/ uploads / 2013/05/ encuesta-flash-tabacodemoscopica-abril-2013.pdf.

26. Borland R, Yong HH, Cummings KM, et al. Determinants and consequences of smoke-free homes: findings from the International Tobacco Control (ITC) Four Country Survey. Tob Control 2006; 15(Suppl 3):iii42-50.

27. Zheng ZL, Deng HY, Wu CP, et al. Secondhand smoke exposure of children at home and prevalence of parental smoking following implementation of the new tobacco control law in Macao. Public Health 2017; 144:57-63.

28. Rosen LJ, Myers V, Winickoff JP, et al. Effectiveness of Interventions to Reduce TobaccoSmokePollution in Homes: A Systematic Review and Meta-Analysis. Int J Environ Res Public Health 2015; 12(12):16043-59.

29. Baxi R, Sharma M, Roseby R, etal. Family and carer smoking control programmes for reducing children's exposure to environmental tobacco smoke. Cochrane Database Syst Rev 2014; (3):CD001746. 